\title{
An annotated catalogue of Recent Pectinoidea (Mollusca, Pectinidae and Propeamussiidae) type material in the Museum of Natural History, Humboldt University, Berlin
}

\author{
Henk H. Dijkstra ${ }^{*}, 1$ and Frank Köhler ${ }^{* *, 2}$ \\ ${ }^{1}$ Zoological Museum, University of Amsterdam, PO Box 94766, 1090 GT Amsterdam, The Netherlands \\ 2 Museum of Natural History, Humboldt University, Invalidenstraße 43, 10115 Berlin, Germany
}

Received 8 May 2007

Accepted 9 August 2007

Published 17 March 2008

\section{Key Words}

ZMB

Bivalvia

nomenclature

taxonomy

lectotype designation

\begin{abstract}
This paper lists 22 pectinoid types (21 primary and one secondary) and three potential syntypes in the Museum of Natural History (ZMB) in Berlin. Eight lectotypes are designated herein for the stabilization of taxonomic names: Pecten aequatorialis, Pecten australis, Pecten clathratus, Camptonectes gaussianus, Pecten nigromaculatus, Pecten puncticulatus, Pecten pycnolepis and Pecten vesiculosus. Nomenclatural notes on the types and further specimens are provided and the current systematic positions of the covered taxa are reported.
\end{abstract}

\section{Introduction}

The senior author visited the Museum für Naturkunde der Humboldt-Universität (ZMB) in 1989 on the invitation of the late Dr. Rudolf Kilias, then curator of the malacological collection, to study the pectinoid collection, which was rather in generic disorder and had not been updated for decades. Type material was not adequately marked and therefore often remained unidentified among the rest of the main collection.

The extensive collection of the ZMB contains material from various provenances. Especially significant because of their historical importance are shells that stem from the former collections of mainly German malacologists, such as R. A. Philippi, W. Dunker, C. E. Lischke, F. M. Hilgendorf, F. Paetel, J. C. Godeffroy, H. Rolle (separated), E. von Martens, and H. von Maltzan. In addition, the museum houses specimens obtained from various foreign collectors like T. A. di Monterosato, H. C. Fulton, C. A. Récluz, V. de Robillard, M. M. Schepman, A. Bavay and others. Many specimens were examined and determined by A. Bavay, a keen Pectinidae specialist of the MNHN, at the begin- ning of the 20th century. Deep-sea pectinoids mainly come from the German expeditions on board the vessels "Valdivia", "Gazelle" and "Gauss". Several type specimens were donated to the museum, like that of Pecten dichrous Suter, 1909, and Pecten farreri Jones \& Preston, 1904, and possible also of Pecten turtoni Smith, 1890.

All lectotype and paralectotype designations are made herein in accordance with Article 74.7 (ICZN, 1999). The purpose of these designations is to facilitate the ongoing taxonomic revision of the group and to prevent potential taxonomic instability that might result upon identification of individuals of more than one species in a given types series and the discovery of implied but not located members of the type series. In a few cases where the status of specimens and the original description and illustration could not be established but potential type material was identified, such specimens are discussed as potential type material.

\section{Acronyms and abbreviations}

BMNH The Natural History Museum, London

KBIN Koninklijk Belgisch Instituut voor Natuurwetenschappen, Brussels

\footnotetext{
* E-mail: H.H.Dijkstra@uva.nl

** Corresponding author, e-mail: frank.koehler@museum.hu-berlin.de
} 
LMD

Loebbecke-Museum und Aquazoo, Düsseldor

MNHS Museo Nacional de Historia Natural, Santiago de Chile

NMW National Museum of Wales, Cardiff

ZMB Museum of Natural History, Berlin

ZSI Zoological Survey of India, New Alipur, Calcutta

$\mathrm{H} \quad$ Height (umbonal-ventral direction of disc)

L Length (anterior-posterior direction of disc)

lv left valve (upper valve)

rv right valve (lower valve)

* typically used to mark type material on ZMB labels and in the collection catalogue

\section{Alphabetical list of taxa}

\section{Pecten (Pseudamusium) [sic] aequatorialis Thiele in Thiele \& Jaeckel, 1931 \\ (Figure 1a)}

Thiele \& Jaeckel, 1931: 165, pl. 1, fig. 2

Barnard, 1963: 14

Type locality. Deutsche Tiefsee-Expedition "Valdivia" stn 191, eastern Indian Ocean, Indonesia, off Sumatra, Siberut Island, $0^{\circ} 39^{\prime} 2^{\prime \prime} \mathrm{S}$ (-0.650556), 98 $52^{\circ} 3^{\prime \prime} \mathrm{E}$ (98.8675), $750 \mathrm{~m}$, dead.

Type material. Lectotype, present designation, ZMB Moll. 111.640a ("Pecten (Pseudamusium) aequatorialis Th."/Siberut-Insel, Stat. 191, Valdivia"; left valve: $\mathrm{H}=4.4 \mathrm{~mm}, \mathrm{~L}=4.4 \mathrm{~mm}$ ).

Sixteen paralectotypes ZMB Moll. 111.640b. 64 paralectotypes ZMB Moll. 78.437 (“Pecten (Pseudamusium) aequatorialis Th.*/Ostafrika, Stat. 251, Valdivia”).

Remarks. According to the ICZN (1999: 87, art. 76.2) the type locality is restricted to station number 191. It is not possible to unambiguously identify the valve figured in the original description. Measurements of the figured valve were given by Thiele in Thiele \& Jaeckel (1931) as $\mathrm{H}=4.2 \mathrm{~mm}, \mathrm{~L}=4.5 \mathrm{~mm}$. The specimen figured herein and selected as the lectotype, closely matches this size. Thiele placed this small species in the subgenus "Pseudamusium" (err. pro Pseudamussium) of Pecten, which in fact is not a pectinid, but a propeamussiid.

The current systematic position is Cyclopecten aequatorialis (Thiele in Thiele \& Jaeckel, 1931), which is placed in the family Propeamussiidae.

Presently no other records are known than the two localities reported in the original description, viz. near Siberut Island and Zanzibar Channel of the western Indian Ocean. Only dead shells were dredged from 693$750 \mathrm{~m}$ depth.

\section{Pecten albolineatus G. B. Sowerby II, 1842}

(Figure 2a)

G. B. Sowerby II, 1842: 73, pl. 14, figs 69, 70

Reeve, 1853: species 95, pl. 24, fig. 94b

Küster \& Kobelt, 1888: 75-76, pl. 19, fig. 3

Dijkstra, 1998a: 39, pl. 8, figs $1-3$

Type locality. "Guimaras, Philippines." (Philippines, Guimaras Island, $10.58444 \mathrm{~N}, 122.61583 \mathrm{E})$
Type material. Two possible syntypes ZMB Moll. 114.614 ("Pecten albolineatus, Sw./Philippinen/H. Cuming”, "P. albolineatus, Sow. Thes. Conch. p. 73 pl. 14f. 69"; typical label of the Dunker collection; three pairs of articulated valves: a) $\mathrm{H}=22.6 \mathrm{~mm}, \mathrm{~L}=19.5 \mathrm{~mm}$, b) $\mathrm{H}=17.9, \mathrm{~L}=15.4 \mathrm{~mm}, \mathrm{c}) \mathrm{H}=20.2, \mathrm{~L}=16.6 \mathrm{~mm}$ ).

Six syntypes are in the BMNH (1994163); the largest specimen figured by Reeve (1853: pl. 24, fig. 94b) closely fits the measurements of the original description.

Remarks. The present specimens were obtained by Dunker from H. Cuming and are considered as probable types.

The current systematic position is Mimachlamys albolineata (G. B. Sowerby II, 1842), which is placed in the family Pectinidae. The species is living sublittorally in the (sub)tropical western and southwestern Pacific.

\section{Pecten australis Philippi, 1845}

(Figure 2b)

Philippi, 1845: 56-57; Martens, 1881a: 79

Stempell, 1899: 228 (Pecten rosaceus, a nomen novum for Pecten australis Philippi)

Hertlein, 1935: 305 (Pecten (Chlamys) amandi, a nomen novum for Pecten australis Philippi)

Grau, 1959: 81, 83-84

Roth, 1975: 85, text-fig. 1 (as "holotype" of Chlamys amandi $($ Hertlein $)=$ a nomen novum for Pecten australis Philippi)

Waloszek, 1984: 218, pl. 2, fig. 6 (as "cotype"); Jonkers, 2003: 46

Type locality. "Insulae Chonos" (Chonos Archipelago), SE Pacific, Chile.

Type material. Lectotype, present designation, ZMB Moll. 16.193 (“Pecten australis Phil./Wiegm. Arch. 1845/Magellanstr./16193/Philippi"; one pair of matching valves: $\mathrm{H}=17 \mathrm{~mm}, \mathrm{~L}=15 \mathrm{~mm}$ ).

Cited measurements in Prussian Linien $(1$ Linie $=2.18 \mathrm{~mm})$ : "Alt. $101 / 4^{\prime \prime \prime} \quad(\mathrm{H}=22.3 \mathrm{~mm}), \quad$ diam. $9^{\prime \prime \prime} \quad(\mathrm{L}=19.6 \mathrm{~mm})$, crass. $31 / 3^{\prime \prime \prime}$ (Thickness $7.3 \mathrm{~mm}$ )."

Remarks. Roth (1975: 85) referred to a holotype of Pecten australis Philippi, 1845 in the MNHS. However, a holotype does not exist because the description is not explicitly based on a single specimen. Roth (1975) did not select a lectotype by interference of the holotype (ICZN, Art. 74.6) and gave no measurements and depicted left and right valves of different sizes (textfig. 1, p. 85), which consequently stem from two different individuals. Because of the sparse information given by Roth (1975) on label or catalogue data associated with the MNHS data, we are not able to evaluate the status of the MNHS specimen at this point. As a consequence, we consider the respective valves as possible syntypes only.

In the ZMB collection, there is a second shell that closely matches the measurements given by Philippi. It originates from the Paetel collection and is accompanied by a label "Magellan Str". On the outside of the right valve of the largest specimen is an old cross mark in ink, possibly indicating that this specimen is a type. However, because Paetel generally replaced all original labels with his own labels, the origin of the present specimen remains unclear. 
The name introduced by Philippi (1845) is preoccupied by Pecten australis Sowerby II, 1842 and therefore permanently invalid. Stempell (1899) introduced a nomen novum (replacement name), Pecten rosaceus, which is also preoccupied (Grau 1959: 83). A new replacement name was subsequently introduced by Hertlein (1935: 305): Pecten (Chlamys) amandi.

The taxon is a junior synonym of Psychrochlamys patagonica (King \& Broderip, 1832) according to Jonkers (2003: 43), placed in the family Pectinidae. The species occurs on the Patagonian shelf of southeastern South America, as far north as Uruguay, off the Falkland Islands, and in the Magellan Region to south of Tierra del Fuego (Jonkers 2003: 46).

\section{Pecten bernardi Philippi, 1851}

(Figure 2c)

Philippi, 1851: 90; Hayami, 1984: 99

Wagner, 1989: 55, fig. 3 ("holotype" BMNH 1923.7.13.7)

Raines \& Poppe, 2006: 312, 313 (figs [not numbered]), pl. 274, figs 1,4
Type locality. Not specified.

Type material. Three possible syntypes ZMB Moll. 103.076 (pairs of disarticulated valves: a) $\mathrm{H}=21.0 \mathrm{~mm}, \mathrm{~L}=22.0 \mathrm{~mm}$; b) $\mathrm{H}=21.5 \mathrm{~mm}$, $\mathrm{L}=23.5 \mathrm{~mm}$; c) $\mathrm{H}=23.0 \mathrm{~mm}, \mathrm{~L}=24.0 \mathrm{~mm}$.

Cited measurements in Prussian Linien $(1$ Linie $=2.18 \mathrm{~mm})$ by Philippi (1851: 90): "Long. 10"' $(\mathrm{L}=21.8 \mathrm{~mm})$; alt. ab umbonibus ad ventrem $91 / 2^{\prime \prime \prime}(\mathrm{H}=20.7 \mathrm{~mm})$; crass. $7^{\prime \prime \prime}$ (Thickness $\left.15.3 \mathrm{~mm}\right)$; auricula antica $4^{\prime \prime \prime}$ (Anterior auricle $8.7 \mathrm{~mm}$ ), postica $21 / 4^{\prime \prime \prime}$ (Posterior auricle $4.9 \mathrm{~mm}$ ) longa."

Remarks. Specimen 103.076 was marked with an ' $\mathrm{X}$ ' on the inner side by Waller. It is figured herein and conforms perfectly to Philippi's measurements. A note by Waller states that this specimen might be suitable for the designation of a lectotype. However, the entire lot is not accompanied by any original information on its origin (such as old labels or catalogue entries). It has been stated to be of type status by Waller and subsequently has been incorporated as such in the main catalogue of the collection. However, in the absence of any reliable historical information, at this point we refrain from a lectotype designation because there is insufficient evidence that the present material indeed is of type status. Rather, we tentatively consider the pre-

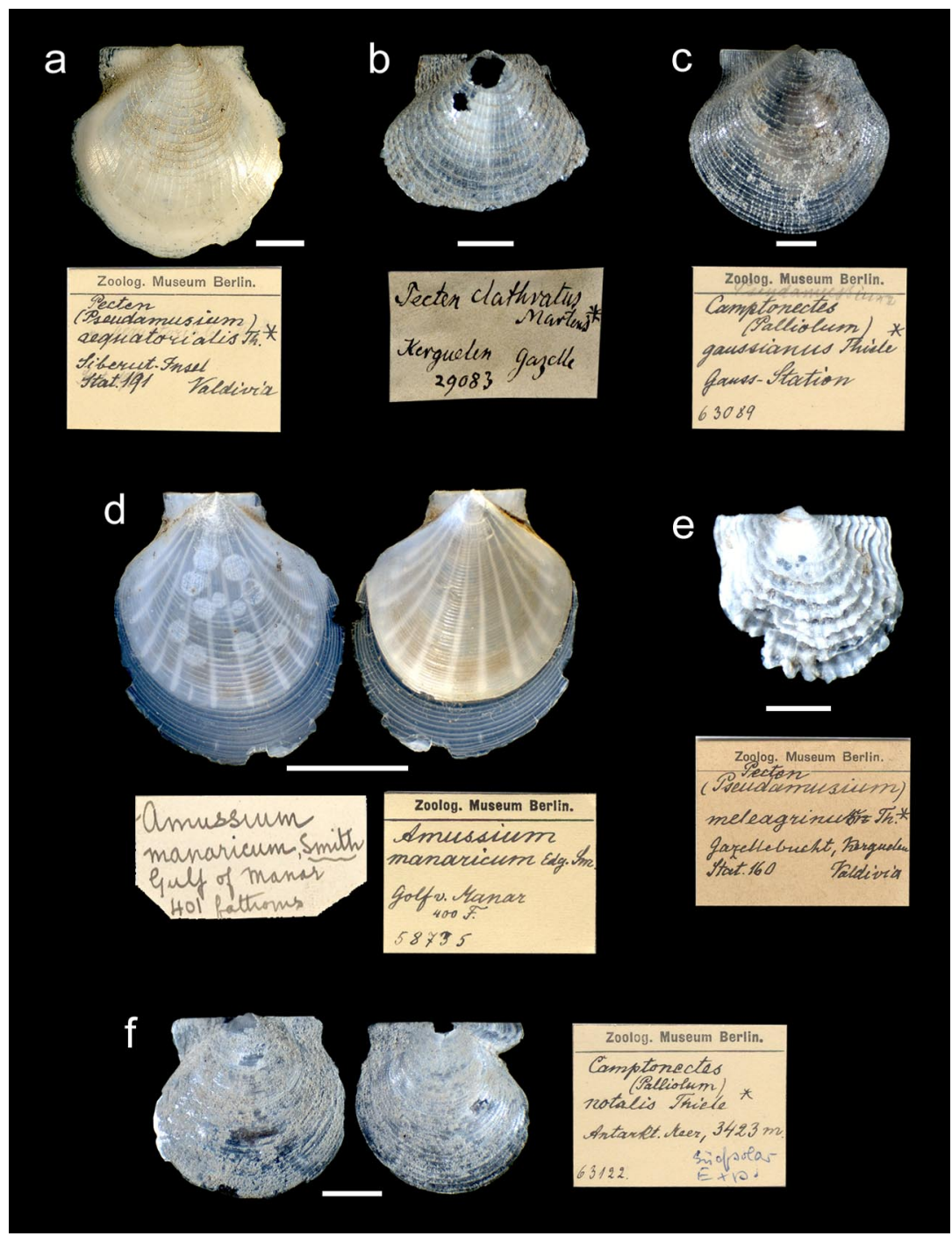

Figure 1. Pectinoid types in the $\mathrm{ZMB}$ and original labels. a. Lectotype of Pecten (Pseudamusium) aequatorialis ZMB Moll. 111.640a (lv); b. Lectotype of Pecten clathratus ZMB Moll. 29.083 (lv); c. Lectotype of Camptonectes (Palliolum) gaussianus ZMB Moll. 63.089a (lv visible); d. Syntype of Amussium manaricum ZMB 58.735 (lv, rv); e. Holotype of Pecten (Pseudamusium) meleagrinus ZMB Moll. 111.639 (lv visible); f. Holotype of Camptonectes (Palliolum) notalis ZMB Moll. 63.122 (lv, rv). Scale bars $=1 \mathrm{~mm}(\mathrm{a}-\mathrm{c}, \mathrm{e}-\mathrm{f}), 10 \mathrm{~mm}(\mathrm{~d})$. 

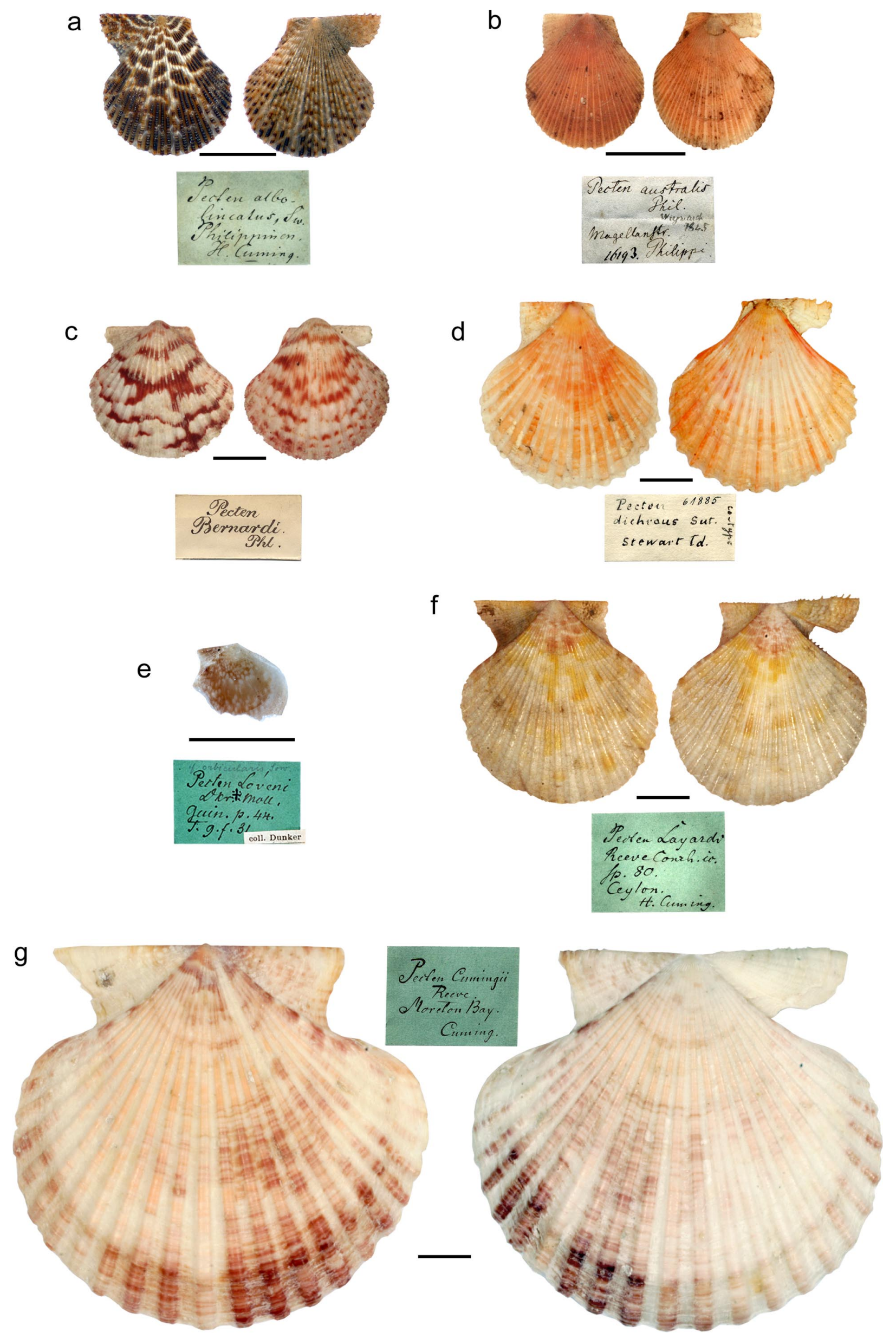
sent specimens as possible syntypes only. A further type specimen was reported by Wagner (1989), which was later followed by Raines \& Poppe (2006: 312). These authors incorrectly referred to a "holotype" of Pecten bernardi Philippi, 1851 in The Natural History Museum, London (BMNH 1923.7.13.7). However, the BMNH specimen is not a type of the taxon, as can be concluded from examination of the specimen, sales lists, and correspondence of the museum by the senior author.

Neither MNHS nor MNHN hold type material of this species (O. Gálvez Herrera, pers. comm., 25 September 1989; Bernard Métivier, MNHN pers. comm.). The current systematic position of this species is Cryptopecten bernardi (Philippi, 1851), placed in the family Pectinidae. The species lives sublittorally to bathyally throughout French Polynesia (Raines \& Poppe, 2006).

\section{Pecten clathratus Martens, 1881}

(Figure 1b)

Martens, 1881b: 79

Smith, 1885: 305, pl. 22, figs 4-4a

Küster \& Kobelt, 1888: 154-155, pl. 43, figs 6, 7

Dijkstra, 1998b: 245-246 (Cyclopecten martensi, a nomen novum for Pecten clathratus)

Type locality. "Gazelle”, near Kerguelen Island, 49¹' S (-49.01667), $70^{\circ} 44^{\prime}$ E (70.73333).

Type material. Lectotype, present designation, ZMB Moll. 29.083 ("Pecten clathratus Martens*/Kerguelen/Gazelle/29083" in the handwriting of von Martens, left valve).

Cited measurements by Martens (1881b: 79): "Alt. et long. (lat.) $31 / 2$ mm."

The small, fragile figured specimen is seriously damaged and measurements are only possible of the length of the shell $(\mathrm{L}=3.7 \mathrm{~mm})$.

Remarks. The original description was not explicitly based one left valve, but also on a right valve. The present specimen is the only type currently known to exist. It is here designated the lectotype.

Martens' name is preoccupied by Pecten clathratus Eichwald, 1830, a fossil species from Litvia, as well as Pecten clathratus Roemer, 1836, a fossil species from the Jurassic of Germany, and therefore invalid. Dijkstra (1998b) introduced Cyclopecten martensi as a replacement name.

This propeamussid species is only recorded from near Kerguelen Island (Martens, 1881b; Smith, 1885) and Alexander Island, Antarctica (Powell, 1960) in bathyal depths.

\section{Pecten cumingii Reeve, 1853}

(Figure 2g)

Reeve, 1853: species 140, pl. 31, figs 140a, 140b

Küster \& Kobelt, 1888: 215-216, pl. 58, figs 1, 2

Raines \& Poppe, 2006: 330, pl. 288, figs $1-7$, pl. 289, figs $1-7$

Type locality. "Moreton Bay, Australia." (Australia, southern Queensland, Moreton Bay).

Type material. Syntype ZMB Moll. 114.613 ("Pecten cumingii Reeve/ Moreton Bay/Cuming", typical green label from the Dunker collection, in the handwriting of Dunker; pair of disarticulated valves; $\mathrm{H}=72.0 \mathrm{~mm}, \mathrm{~L}=77.8 \mathrm{~mm})$.

Five syntypes BMNH (1950.11.14.3-7); pairs of matching valves. The largest specimen matches the specimen figured by Reeve (1853: pl. 31, fig. 140a).

Remarks. The species was evidently described for more than a single specimen because Reeve (1853) depicted two different shells. It was described from shells collected by Strange as part of the Cuming collection, which is presently housed at BMNH. The ZMB specimens are similar but not identical with the figured specimens. They were obtained by Dunker from Cuming and are therefore considered part of the type series.

The current systematic position of this species is Volachlamys singaporina (G. B. Sowerby II, 1842), placed in the family Pectinidae. The species is living sublittorally in the tropical southwestern Pacific.

\section{Pecten (Chlamys) dichrous Suter, 1909}

(Figure 2d)

Suter, 1909: 264, pl. 11, fig. 31

Suter, 1913: 875 , pl. 52, fig. 1

Beu, 1995: 17, figs $3 \mathrm{e}-\mathrm{h}$

Jonkers, 2003: 56, pl. 11, figs h-k

Raines \& Poppe, 2006: 284, pl. 235, figs 1-6

Type locality. Port Pegasus, Stewart Island, New Zealand, ex blue cod (Parapercis colias).

Type material. Two paralectotypes ZMB Moll. 61.885 ("Pecten dichrous Sut. Stewart Id./co-type", ded. Suter; left valve: $\mathrm{H}=35.0 \mathrm{~mm}$, $\mathrm{L}=33.0 \mathrm{~mm}$; right valve: $\mathrm{H}=36.0 \mathrm{~mm}, \mathrm{~L}=35.0 \mathrm{~mm}$ ). It is possible that the two very similarly sized valves were formerly interpreted as a pair of matching valves.

Lectotype NZGS TM 209; two further paralectotypes NMNZ M.10967 (1 pair, 1 valve).

Cited measurements by Suter (1909: 264): "Length 32, height 36, diam. [thickness] $10 \mathrm{~mm} . "$

Remarks. The lectotype was designated by Boreham (1959: 10). The current systematic position of this species is Talochlamys dichroa (Suter, 1909) in the family

Figure 2. Pectinoid types in the ZMB and original labels, continued; a. Syntype of Pecten albolineatus ZMB Moll. 114.614 (lv, rv); b. Lectotype of Pecten australis ZMB Moll. 16.193a (lv, rv); c. Possible syntype of Pecten bernardi ZMB Moll. 103.076a (lv, rv); d. Paralectotype of Pecten dichrous ZMB Moll. 61.885 (lv, rv); e. Holotype of Pecten loveni ZMB Moll. 103.369 (lv); f. Syntype of Pecten layardi ZMB Moll. 114.611 (lv, rv); g. Syntype of Pecten cumingii ZMB Moll. 114.613 (lv, rv). Scale bars $=10 \mathrm{~mm}$. 

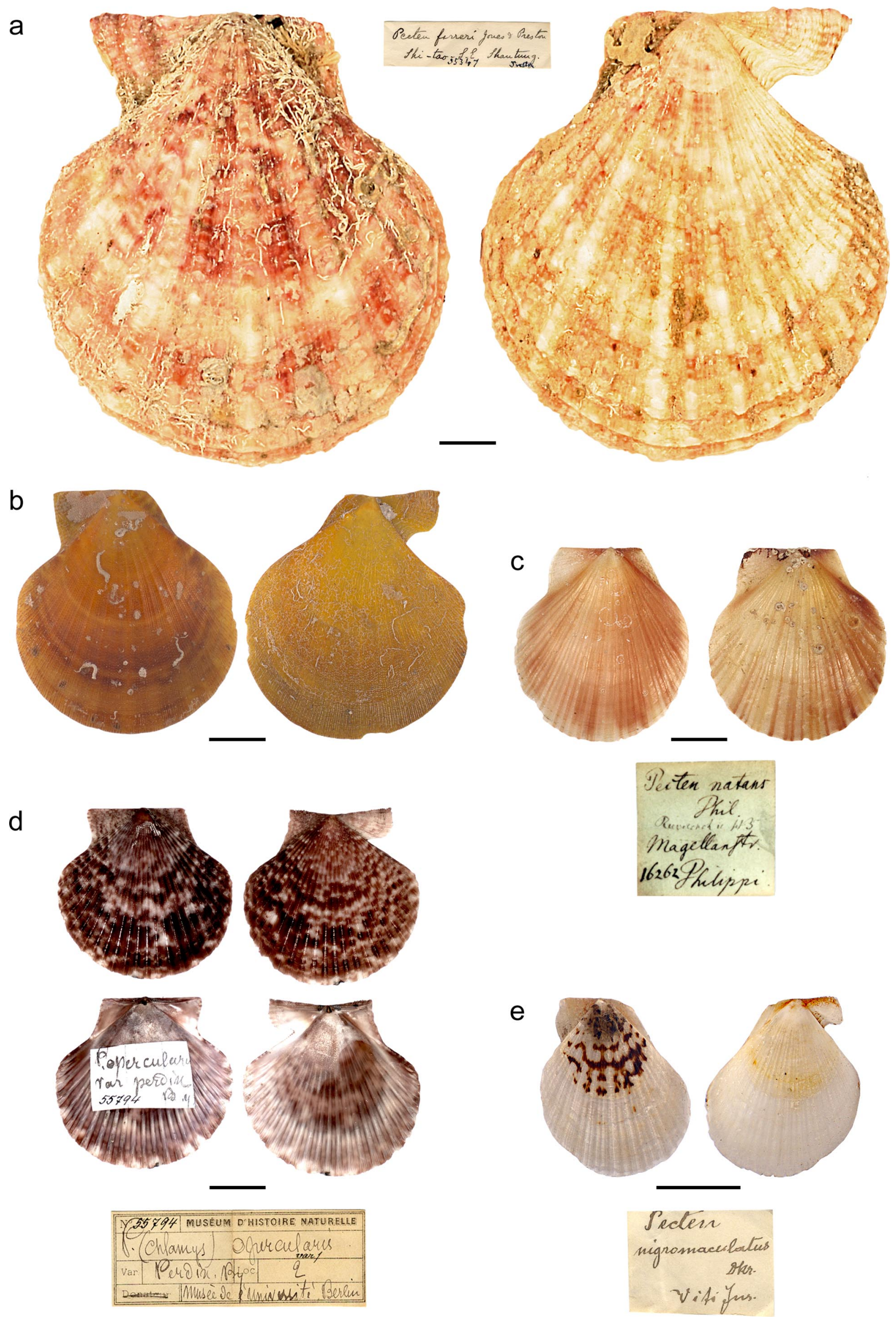
Pectinidae. This bathyal species is known only from off New Zealand.

\section{Pecten (Chlamys) farreri Jones \& Preston, 1904 (Figure 3a)}

Jones \& Preston, 1904: 149, text-fig.

Raines \& Poppe, 2006: 228, pl. 145, figs 1-3, pl. 176, figs $1-3$, pl. 177 , figs $1-8$

Type locality. "Shi Tao, Shantung" (northeastern China, Shandong Sheng, Shitau).

Type material. Syntype ZMB Moll. 55.347 ("Pecten farreri Jones \& Preston/Shi-Tao, SE Shantung" in the handwriting of Preston; ded. Preston as type; pair of articulated valves: $H=80.0 \mathrm{~mm}$, $\mathrm{L}=72.0 \mathrm{~mm}$ ).

Syntype ZMB Moll. 59.188 ("Pecten farreri Jones \& Preston/ShiTao, SE Shantung" in the handwriting of Preston; ded. Preston as type; pair of articulated valves: $\mathrm{H}=80.0 \mathrm{~mm}, \mathrm{~L}=69.0 \mathrm{~mm}$ ).

Measurements cited by Jones \& Preston (1904: 149): “Long. 81, lat. $75 \mathrm{~mm} . "$

Remarks. Further type material is housed in other museums: Two syntypes BMNH 1903.12.20.6-7 (pairs of articulated valves, of which the largest shell is the figured specimen in the original description); syntype MNHN (not registered, pair of articulated valves); two syntypes NMW 19.141.794 (pairs of articulated valves).

The current taxonomic position of this species is Azumapecten farreri (Jones \& Preston, 1904), placed in the family Pectinidae. It lives along the coasts of northern China, Korea, and eastern Russia and in Japanese waters in littoral and sublittoral depths.

\section{Camptonectes (Palliolum) gaussianus Thiele, 1912 (Figure 1c)}

Thiele, 1912: 226, pl. 17, figs 2-2a

Egorova, 1985: 19, fig. 12

Hain, 1990: 89, pl. 13, figs $4 a-c$

Type locality. Deutsche Süd-Polar Expedition 1901-1903, Antarctic Sea, Gauss Station (ca. $66^{\circ} 3^{\prime} \mathrm{S} 89^{\circ} 38^{\prime} \mathrm{E}$ ), alive.

Type material. Lectotype, present designation, ZMB Moll. 63.089a ("Camptonectes (Palliolum) gaussianus Thiele*/Gauss-Station/ 63089"; pair of articulated valves: $\mathrm{H}=43.0 \mathrm{~mm}, \mathrm{~L}=46.0 \mathrm{~mm}$ ).

Paralectotype ZMB Moll. 63.089b (left valve: $\mathrm{H}=36.0 \mathrm{~mm}$, $\mathrm{L}=39.0 \mathrm{~mm}$ ).

$\sim 50$ paralectotypes ZMB Moll. 63.089c (“Camptonectes (Palliolum) gaussianus Thiele 1912/Gauss-Station /DSE"; in ethanol).

Cited measurements by Thiele (1912: 226): "Die abgebildete Schale ist 4,25 $\mathrm{mm}$ hoch und unbedeutend länger." (The figured shell is $4.25 \mathrm{~mm}$ high and barely longer). The largest specimen is closest in size to Thiele's measurements. We were not able to unambiguously identify the specimen figured in the original description. The specimen figured herein is designated the lectotype. It fits the size given by Thiele (1912).
Remarks. The taxonomic position of this species is $C y$ clochlamys gaussianus (Thiele, 1912), placed in the family Propeamussiidae. This bathyal species occurs in Antarctic waters (Hain, 1990).

\section{Pecten layardi Reeve, 1853}

(Figure 2f)

Reeve, 1853: species 80 , pl. 21, figs $80 \mathrm{a}, 80 \mathrm{~b}$ Küster \& Kobelt, 1888: 170-171, pl. 47, figs 4, 5 Dijkstra \& Marshall, 1997: 102 (type data and synonymy) Dijkstra \& Kilburn, 2001: 305, figs 44-45

Type locality. Ceylon (Sri Lanka).

Type material. Syntype ZMB Moll. 114.611 ("Pecten layardi Reeve/ Conch Ic. sp. 80/Ceylon/H. Cuming", typical green label from the Dunker collection, in the handwriting of Dunker; pair of disarticulated valves; $\mathrm{H}=38.5 \mathrm{~mm}, \mathrm{~L}=37.0 \mathrm{~mm}$ ).

Syntype ZMB Moll. 114.612 ("Pecten layardi Reeve/Conch Ic. sp. $80 /$ Ceylon/H. Cuming", "layardi" subsequently crossed out by von Martens and replaced with ("tranquebaricus"), typical green label from the Dunker collection, in the handwriting of Dunker; two pairs of disarticulated valves: a) $\mathrm{H}=39.4 \mathrm{~mm}, \mathrm{~L}=38.3 \mathrm{~mm}, \quad$ b) $\mathrm{H}=35.9 \mathrm{~mm}, \mathrm{~L}=36.7 \mathrm{~mm}$ ).

Six syntypes BMNH 1994.162. Two syntypes are figured by Reeve (1853: pl. 21, figs $80 \mathrm{a}, 80 \mathrm{~b})$.

Remarks. The species was evidently described from more than a single specimen because Reeve (1853: pl. 21, figs $80 \mathrm{a}, 80 \mathrm{~b}$ ) depicts for different shells. The species was described for shells collected by Layard and part of the Cuming collection, which is presently housed in the BMNH. The ZMB specimens are similar but not identical with the figured specimens. They were obtained by Dunker from Cuming and are therefore considered as part of the type series.

The current taxonomic position of this species is $M i$ machlamys sanguinea (Linnaeus, 1758), placed in the family Pectinidae. This sublittoral species occurs throughout the (sub)tropical Indo-Pacific.

\section{Pecten loveni Dunker, 1853}

(Figure 2e)

Dunker, 1853: 44, pl. 9 , fig. 31

Grau, 1959: 60

Dijkstra \& Goud, 2002: 52-53, figs 45-48

Raines \& Poppe, 2006: 74, pl. 9, figs $1-7$, pl. 10, figs $1-7$

Type locality. “... ex regione urbis Loandae ...” (Angola, Luanda).

Type material. Holotype ZMB Moll. 103.369 (Pecten loveni Dunker*/ Moll. Guin. p. 44, T. 9 f. 31 ", typical green label of the Dunker collection, in the handwriting of Dunker; asterisk in the handwriting of Martens; single right valve, damaged).

Figure 3. Pectinoid types in the ZMB and original labels, continued; a. Syntype of Pecten (Chlamys) farreri ZMB Moll. 55.347 (lv, rv); b. Shell of Laevichlamys multisquamatus from the Dunker collection, erroneously designated as lectotype by Waller (1993) and potential future neotype (lv, rv); c. Lectotype of Pecten natans ZMB Moll. 16.262a (lv, rv); d. Holotype of Pecten (Chlamys) opercularis var. perdix ZMB Moll. 55.794 (lv, rv, exterior above, inside below); e. Lectotype of Pecten nigromaculatus ZMB Moll. 114.608 (lv, rv). Scale bars $=10 \mathrm{~mm}$. 
Cited measurements by Dunker (1853: 44): "Alt $41 / 3$ lin. Alt., long., crass. ratio fere haec est 100:95:30." $(\mathrm{H}=9.4 \mathrm{~mm}$, $\mathrm{L}=9.0 \mathrm{~mm}$, Thickness $=2.8 \mathrm{~mm}$ ).

Remarks. The original description is based on two valves of a single juvenile, hence the holotype. Of these two valves, only the damaged right valve is present ( $\mathrm{H} \mathrm{ca} .9 \mathrm{~mm})$.

This taxon is a junior synonym of Lissochlamis exotica (Dillwyn, 1817), placed in the family Pectinidae. This species occurs along the tropical West African coast from Mauritania southwards to Angola (Dijkstra \& Goud, 2002), living littorally on soft bottom assemblages.

\section{Amussium manaricum Smith, 1906 \\ (Figure 1d)}

Smith, 1906: 256

Type locality. "Investigator" stn 333, Gulf of Manar, 401 fathoms (733 m); stn 322, Andaman Islands, 378 fathoms (691 m).

Type material. Syntype ZMB 58.735 (“Amussium manaricum Smith/ Gulf of Manar/401 fathoms"; pair of articulated valves; material obtained from Sowerby \& Fulton).

Seven syntypes BMNH 1906.10.12.91-98 (pairs of articulated valves).

Syntype NMW 1955.158.786 (a pair of matching valves).

Syntype ZSI M 3748/1 (a pair of articulated valves).

Cited measurements by Smith (1906: 256): "Longit. $24.5 \mathrm{~mm}$., alt. 26, diam. [thickness] 4.5."

Remarks. The current taxonomic position of this species is Propeamussium manaricum (Smith, 1906), placed in the family Propeamussiidae. So far only recorded from the type locality and lives bathyally on soft bottom assemblages.

\section{Pecten (Pseudamusium) meleagrinus Thiele in Thiele \& Jaeckel, 1931 \\ (Figure 1e)}

Thiele in Thiele \& Jaeckel, 1931: 164-165, pl. 1, figs 1-1a (figs 1a, $\mathrm{b}$ in text)

Type locality. "Valdivia" stn 160, Kerguelen, "Gazellebucht", alive.

Type material. Holotype ZMB Moll. 111.639 ("Pecten (Pseudamusium) meleagrinus Th. "/Gazellebucht, Kerguelen, Stat. 160/Valdivia"; pair of disarticulated valves).

Cited measurements by Thiele in Thiele \& Jaeckel (1931: 165): "Länge des Schloßrandes 2,6 mm, Höhe der linken Schale 2,45 mm, Höhe der rechten $2,15 \mathrm{~mm}$." The marginal apron of the right valve is broken off. This is the reason why this valve is somewhat smaller. Normally both valves are equal in size.

Remarks. The original description is based on a single animal ("ein kleines Tier"), hence the holotype. Authority for the name is Thiele, who finished the part on Pectinidae without the help of S. Jaeckel, as is stated in the preface of the volume.

Thiele placed this small species in the subgenus "Pseudamusium" (err. pro Pseudamussium) of Pecten, which in fact is not a pectinid, but a propeamussiid. The current taxonomic position of this species is
Cyclochlamys meleagrina (Thiele in Thiele \& Jaeckel, 1931), which is placed in the family Propeamussiidae. This species is morphologically very close to Pecten aviculoides Smith, 1885, known from Prince Edward Island in 183 to $274 \mathrm{~m}$, as already suggested by Thiele, and perhaps conspecific (under study).

C. meleagrina is so far only recorded from the Kerguelen Islands.

\section{Pecten multisquamatus Dunker, 1864}

(Figure 3b)

Dunker, 1864: 100; Dunker, 1865: 67, pl. 23, figs 1-3

Küster \& Kobelt, 1888: 141-142, pl. 40, fig. 2

Bavay, 1909: 279

Waller, 1993: 205, figs 4a-i, 1, m

Type locality. "Habanam" (Cuba, Havana Bay).

Type material. Not found.

Cited measurements by Dunker (1864: 100): "Altit. testae 64, latit. 58, crass. 11 mill."

Remarks. The description was based on a specimen collected by Gundlach, hence the holotype. Waller (1993: 205) stated that he was not able to trace this specimen in the ZMB or in the Instituto de Ocianología de Cuba. However, most parts of Gundlach's collection were sold to the Spanish Government forming the basis for the Museum of the Institute of Havana (MNHNCU) (Ramsden, 1915: 255). Specimens from the Gundlach collection were also stated to be kept by the Instituto de Ecología y Sistemática de La Habana, Cuba (Fernández Milera et al., 2002). It is possible that the type can be found in either of the latter two institutions. Waller (1993: 205) designated a specimen from the Dunker collection that was collected by Poey in Cuba as the lectotype of P. multisquamatus (ZMB 114.606; pair of disarticulated valves: $\mathrm{H}=43.1 \mathrm{~mm}, \mathrm{~L}=39.5 \mathrm{~mm}$ ) (Fig. 3b). However, because this specimen evidently is not a type, the lectotype designation is invalid according to Article 74.1 of the Code (ICZN, 1999). If no type can be found in other museum collections, the present specimen could be designated as a neotype if this is regarded necessary in a future revision.

The present pectinid species is the type species of the genus Laevichlamys Waller, 1993, by original designation. Pecten effluens Dall, 1886 is a junior synonym (Waller, 1993). The species occurs in sublittoral to bathyal waters throughout the Antilles (tropical western Atlantic).

\section{Pecten natans Philippi, 1845}

(Figure 3c)

Philippi, 1845: 57

Küster \& Kobelt, 1888: 34-35, pl. 7, figs 6, 7

Grau, 1959: 125, pl. 42, figs 1-2

Jonkers, 2003: 60, pl. 2, figs a, c, e, pl. 15, figs a,b

Type locality. In original text: "Fretum Magellanicum, Messier-Canal, Smith-Canal." On original labels: "Magellan Str." 
Type material. Lectotype ZMB Moll. 16.262a (pair of articulated valves: $\mathrm{H}=34.5 \mathrm{~mm}, \mathrm{~L}=32 \mathrm{~mm}$ ), designated by Jonkers (2003: 60).

Four paralectotypes ZMB Moll. 16.262b-e (pairs of articulated valves): b) $\mathrm{H}=34.5 \mathrm{~mm}, \mathrm{~L}=30.5 \mathrm{~mm}$; c) $\mathrm{H}=27.5 \mathrm{~mm}, \mathrm{~L}=26.0 \mathrm{~mm}$; d) $\mathrm{H}=30.5 \mathrm{~mm}, \mathrm{~L}=28.5 \mathrm{~mm}$; e) $\mathrm{H}=23.5 \mathrm{~mm}, \mathrm{~L}=21.0 \mathrm{~mm}$.

Cited measurements by Philippi (1845: 57): "var. a) minor, tenuissima pellucida, $15^{\prime \prime \prime}(\mathrm{H}=32.7 \mathrm{~mm})$ alta, $131 / 2^{\prime \prime \prime}(\mathrm{L}=29.4 \mathrm{~mm})$ lata, $41 / 2^{\prime \prime \prime}$ (Thickness $9.8 \mathrm{~mm}$ ) crassa. var. b) major, solidior, costis 50: $25^{\prime \prime \prime}(\mathrm{H}=54.5 \mathrm{~mm})$ alta, $231 / 2^{\prime \prime \prime}(\mathrm{L}=51.2 \mathrm{~mm})$ lata, $81 / 2^{\prime \prime \prime}$ (Thickness $18.5 \mathrm{~mm}$ ) crass." None of the present type specimens closely matches the original measurements of Philippi.

Remarks. The description is not explicitly based on a single specimen. The largest shell in the type lot has been designated as the lectotype. The current taxonomic position of this pectinid species is Austrochlamys natans (Philippi, 1845) because its two senior synonyms, Pecten vitreus King \& Broderip, 1832, and Pecten corneus Sowerby II, 1842, are permanently invalid for being preoocupied (Jonkers, 2003: 59). Pecten thomasi Sowerby III, 1897 is also a junior synonym. The species is living littorally to sublittorally along the southern coasts of Argentina and Chile south to Bahia Orange.

\section{Pecten nigromaculatus Kobelt in Küster \& Kobelt, 1888}

(Figure 3e)

Kobelt in Küster \& Kobelt, 1888: 273, pl. 71, figs 7-8

Type locality. "Viti-Inseln" (Fiji Islands).

Type material. Lectotype, present designation, ZMB Moll. 114.608 ("Pecten nigromaculatus Dkr/Viti Isl."; pair of articulated valves: $\mathrm{H}=22.0 \mathrm{~mm}, \mathrm{~L}=18.5 \mathrm{~mm}$ ).

Cited measurements by Kobelt in Küster \& Kobelt (1888: 273): "Alt. obliqua 21, diam. $18 \mathrm{~mm}$."

Remarks. The description is based on material from the Paetel collection, accompanied by an unpublished manuscript name of Dunker. However, because no description was published by Dunker, Kobelt in Küster \& Kobelt is the authority for the name (Hertlein 1936; Rehder 1952). Kobelt in Küster \& Kobelt (1888) provided measurements for only a single shell, which is not interpreted as designation of a holotype. The text of the description is silent in regard to the number of specimens on which it is based. Following recommendation 73F (Avoidance of assumption of holotype) of the ICZN (1999), the present specimen is not considered as the holotype. It perfectly fits the figure and measurements provided in the description and is designated as the lectotype. It was originally distributed by Godeffroy from Hamburg and incorporated in the collection of Paetel along with the manuscript name of Dunker. The species is considered a junior synonym of Coralichlamys madreporarum (G. B. Sowerby II, 1842), placed in the family Pectinidae. This coral-dwelling, sublittoral species lives embedded in branches of the fast-growing coral Acropora and occurs throughout the Indo-West Pacific.

\section{Camptonectes (Palliolum) notalis Thiele, 1912}

(Figure 1f)

Thiele, 1912: 251, pl. 17, figs 3-3a

Type locality. Deutsche Süd-Polar Expedition 1901-1903, Antarctic Sea, NW of Gauss Station, $3423 \mathrm{~m}$ depth, alive.

Type material. Holotype ZMB Moll. 63.122 ("Camptonectes (Palliolum) notalis Th.*/Antarkt. Meer, 3423 m/63122 (Südpolar-Exp.”; pair of disarticulated valves: $\mathrm{H}=3.0 \mathrm{~mm}, \mathrm{~L}=3.4 \mathrm{~mm}$ ).

Cited measurements by Thiele (1912: 251): "es ist etwa $3 \mathrm{~mm}$ hoch und lang." ( $\mathrm{H}=\mathrm{L}$ approximately $3 \mathrm{~mm})$. A small part of the marginal apron is broken off of both valves.

Remarks. The description is explicitly based on a single specimen, hence the holotype. Thiele (1912) treated this small specimen as a pectinid and placed it in the subgenus Palliolum of Camptonectes. In fact it belongs in Propeamussiidae as Cyclopecten notalis (Thiele, 1912). It is so far only recorded from the type locality.

\section{Pecten (Chlamys) opercularis var. perdix Bavay, 1906} (Figure 3d)

Bavay, 1906: 245, pl. 7, fig. 2 (right valve)

Type locality. "Provenance inconnue." (Locality unknown).

Type material. Holotype ZMB Moll. 55.794 ("P. (Chlamys) opercularis var. perdix By./?/Museè de l'université Berlin”, typical printed label of Bavay; pair of articulated valves: $\mathrm{H}=31.5 \mathrm{~mm}$, $\mathrm{L}=32.0 \mathrm{~mm}$ ). Inside the left valve an original label is glued with Bavay's handwriting in ink "P. opercularis var. perdix Bavay".

Remarks. The description was explicitly based on a single individual, hence the holotype. The current systematic position of this pectinid is Aequipecten opercularis (Linnaeus, 1758). This common scallop occurs in the littoral to upper bathyal along the coasts of western Europe and northwestern Africa, from southern Norway to Mauritania and the Mediterranean Sea.

\section{Pecten puncticulatus Dunker, 1877}

(Figure 4a)

Dunker, 1877: 71

Dunker, 1882: 244, pl. 11, figs 10-11

Küster \& Kobelt, 1888: 137-138, pl. 38, figs 2-3

Type locality. "Japanis” (Japan).

Type material. Lectotype, present designation, ZMB Moll. 114.469 ("Pecten puncticulatus Dkr *, Japan", two labels of the Dunker collection, text in the handwriting of Dunker, asterisk in the handwriting of von Martens; pair of disarticulated valves: $H=29.0 \mathrm{~mm}$, $\mathrm{L}=32.0 \mathrm{~mm}$ )

Cited measurements by Dunker (1877: 71): "Lat. 33, alt. 30 mill."

Remarks. Dunker (1877) provided measurements for a single shell, which is not interpreted as designation of a holotype. The text of the description is silent in regard to the number of specimens on which it is based. Following recommendation 73F (Avoidance of assumption of holotype) of the ICZN (1999), the present specimen is not considered as the holotype. It 
a

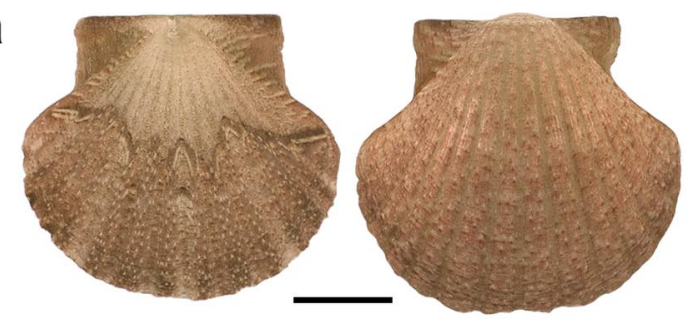

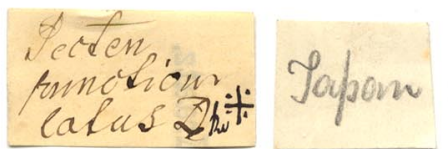
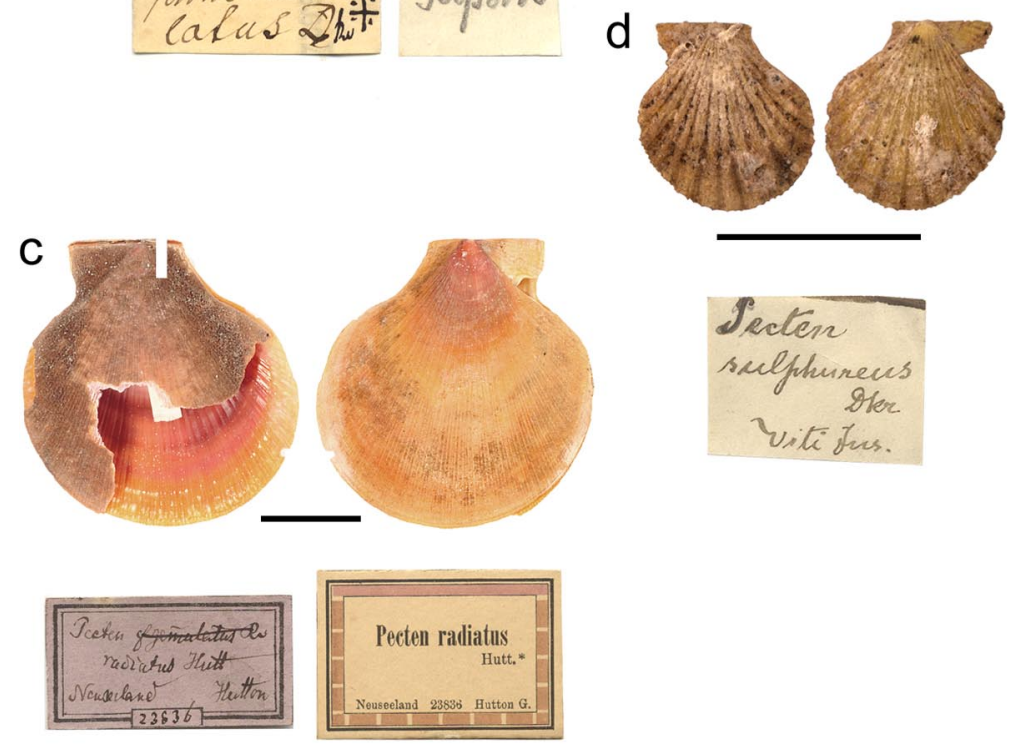

b

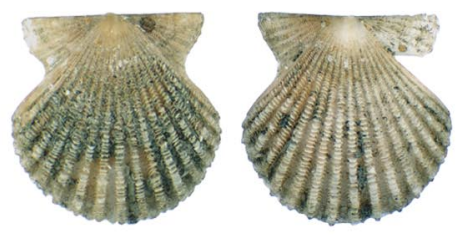

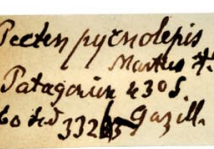
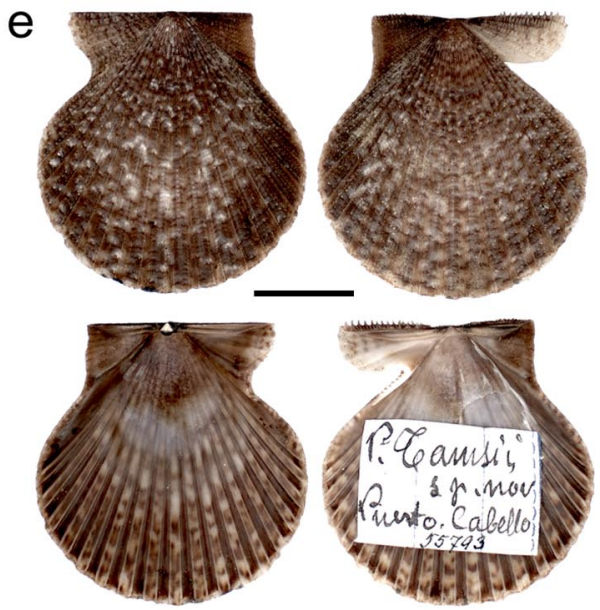

f
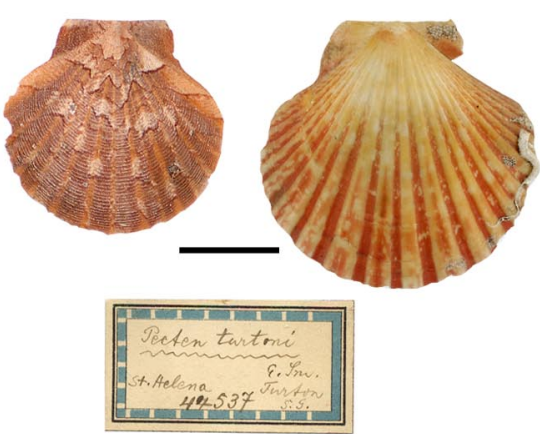

9
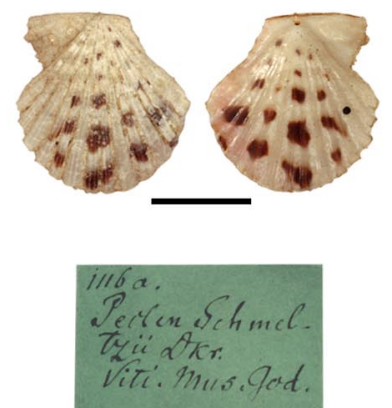

$\mathrm{h}$
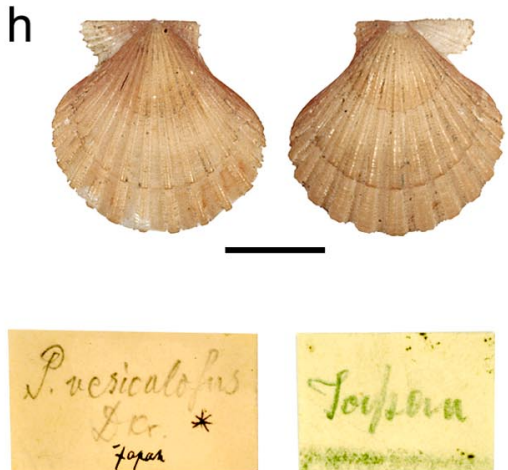

Torbon

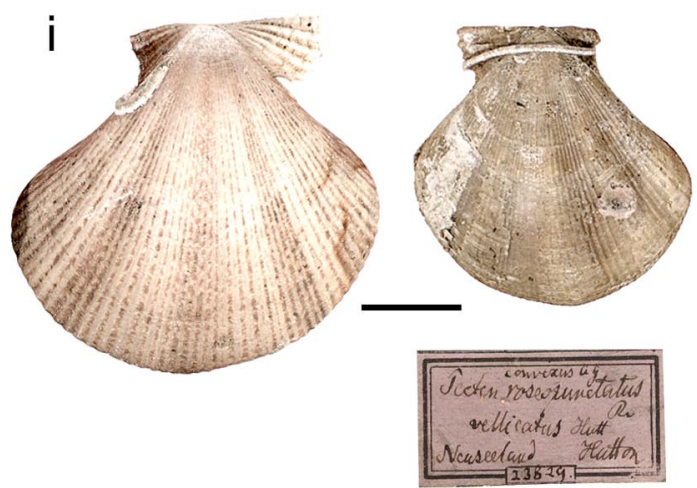


matches the measurements provided in the description and is designated as the lectotype.

The name is a junior synonym of Pecten excavatus Anton, 1838. Also Pecten sinensis Sowerby II, 1842 is considered conspecific, according to Wang (2002: 240). This littoral and sublittoral species lives on soft bottom assemblages in the western Pacific from Japan southwards to the South China Sea.

\section{Pecten pycnolepis Martens, 1881}

(Figure 4b)

Martens, 1881b: 78-79

Type locality. "Gazelle, Ostküste von Patagonien, unter $43^{\circ} 56^{\prime}$ südl. Br., in 60 Faden Tiefe." (East coast of Patagonia, Argentina, $43^{\circ} 56^{\prime} \mathrm{S}$ (-43.93333), $110 \mathrm{~m}$ depth)

Type material. Lectotype, present designation, ZMB Moll. 33.233 ("Pecten pycnolepis Martens*/Patagonien $43^{\circ} \mathrm{S} / 60 \mathrm{Fad} / \mathrm{Gazelle} /$ 33233"; a pair of articulated valves: $\mathrm{H}=14.5 \mathrm{~mm}, \mathrm{~L}=14.0 \mathrm{~mm}$ ).

Cited measurements by Martens (1881b: 78): “Alt. et long. (lat.) 14 , crass. 5 mm."

Remarks. Martens (1881b) provided measurements for a single shell, which is not interpreted as designation of a holotype. The text of the description is silent in regard to the number of specimens on which it is based. Following recommendation $73 \mathrm{~F}$ (Avoidance of assumption of holotype) of the ICZN (1999), the present specimen is not considered as the holotype. It matches the measurements provided in the description and is designated as the lectotype.

The name is a junior synonym of Lindapecten tehuelchus (Orbigny, 1846). Also Pecten vanvincqii Bernardi, 1852 and Pecten darwini Reeve, 1853 are conspecific (Waloszek, 1984: 233). It lives sublittorally to upper bathyally along the eastern coast of South America from southern Brazil to southern Argentina.

\section{Pecten radiatus Hutton, 1873}

(Figure 4c)

\author{
Hutton, 1873: 82 \\ Bavay, 1909: 278 \\ Powell, 1979: 378, pl. 68, fig. 8 \\ Beu, 1995: 19
}

Type locality. Stewart Island, New Zealand, 13 fathoms (24 m).

Type material. Two syntypes ZMB Moll. 23.836 ("Pecten radiatus Hutt. */Neuseeland/Hutton G."; typical museum label of the ZMB; articulated pair of valves, partly broken, and a single valve; a) $\mathrm{H}=60.6 \mathrm{~mm}, \mathrm{~L}=54.3 \mathrm{~mm}, \mathrm{~b}) \mathrm{H}=40.4 \mathrm{~mm}, \mathrm{~L}=40.3$ ).
Three syntypes NMNZ M.350; pairs of matching valves. Cited measurements by Hutton (1873: 82): "Height 1.8 (inch); breadth, 1.7 (inch)."

Remarks. Hertlein (1933: 63) introduced a replacement name: Pecten (Chlamys) suteri for Pecten radiatus Hutton, 1873 (not Gmelin, 1791, or Bosc, 1801) (see also Fleming, 1976: 28). The name is a junior synonym of Pecten gemmulatus Reeve, 1853, which is currently placed in Talochlamys of the family Pectinidae. This species lives sublittorally to bathyally off New Zealand.

\section{Pecten schmeltzii Kobelt in Küster \& Kobelt, 1888 (Figure 4g)}

Dunker, 1869: 116 (nomen nudum) Kobelt in Küster \& Kobelt, 1888: 272, pl. 71, figs 5-6.

Type locality. "Viti-Inseln" (Fiji Islands). On original label two localities: "Viti, Upolu" (Upolu, Samoa).

Non-type material. ZMB holds several specimens that stem from the original series distributed by Godeffroy to various collectors along with the manuscript name of Dunker:

ZMB Moll. 112.618 ("1116a/Pecten schmeltzii Dkr/Viti. Mus. God." coll. Dunker; pair of articulated valves: $\mathrm{H}=12.5 \mathrm{~mm}$, $\mathrm{L}=12.0 \mathrm{~mm}$ ).

ZMB Moll. 112.619 (Lines 1-4: "Pecten schmeltzii Dkr/MG 1116a/ Viti, Upolu", Lines 5-6: "Polynesien coll Dunker"; coll. Paetel ex coll. Dunker; pairs of disarticulated valves: $H=12.0 \mathrm{~mm}$, $\mathrm{L}=11.5 \mathrm{~mm} ; \mathrm{H}=8.5 \mathrm{~mm}, \mathrm{~L}=7.5 \mathrm{~mm} ; \mathrm{H}=8.0 \mathrm{~mm}, \mathrm{~L}=7.5 \mathrm{~mm})$. ZMB Moll. 18.411 ("Pecten schmeltzii Dkr/Viti-Ins., Godeffroy/ 1116a/18411", coll. Godeffroy; pair of valves and single valve).

Cited measurements by Kobelt in Küster \& Kobelt (1888: 272): "Alt oblique 13, diam. 11 Mm."

The largest specimen conforms to the measurements and colouration, but neither of the specimens in ZMB closely matches the original figure.

Remarks. The description was explicitly based on a specimen from the Loebbecke collection, which is currently housed in LMD. Kobelt in Küster \& Kobelt (1888) stated that "under Dunker's manuscript name, other specimens of Pecten with brownish dots were distributed by Godeffroy that partly represent juveniles of other species". These specimens, such as those in the ZMB listed herein, were consciously excluded from the description of the present species and are not qualified as types. The name is a junior synonym of Pascahinnites coruscans coruscans (Hinds, 1845), placed in the family Pectinidae. It lives in tidal to sublittoral waters throughout the Indo-Pacific.

Figure 4. Pectinoid types in the ZMB and original labels, continued; a. Lectotype of Pecten puncticulatus ZMB Moll. 114.469 (lv, rv); b. Lectotype of Pecten pycnolepis ZMB Moll. 33.233 (lv, rv); c. Syntype of Pecten radiatus ZMB Moll. 23.836 (lv, rv); d. Holotype of Pecten sulphureus ZMB Moll. 114.609 (lv, rv); e. Holotype of Pecten (Chlamys) tamsi ZMB Moll. 55.793 (lv, rv); f. Potential syntype of Pecten (Janira) turtoni ZMB Moll. 44.537 (lv, rv); g. Shell of Pascahinnites coruscans coruscans ZMB Moll. 112.618, from the same series of specimens as the holotype of Pecten schmeltzii (lv, rv); h. Lectotype of Pecten vesiculosus ZMB Moll. 114.473 (lv, rv); i. Two syntypes of Pecten (Dentipecten) vellicatus ZMB Moll. 23.829 (lv, rv). Scale bars $=10 \mathrm{~mm}$ 
Pecten sulphureus Kobelt in Küster \& Kobelt, 1888 (Figure 4d)

Kobelt in Küster \& Kobelt, 1888: 276, pl. 72, figs 5-6 Waller, 1972: 231

Type locality. "Viti-Inseln" (Fiji Islands).

Type material. Holotype ZMB Moll. 114.609, ("Pecten sulphureus Dkr./Viti Ins.”, coll. Paetel ex coll. Dunker; a pair of articulated valves: $\mathrm{H}=10.0 \mathrm{~mm}, \mathrm{~L}=9.0 \mathrm{~mm}$ ).

Cited measurements by Kobelt in Küster \& Kobelt (1888: 276): "Alt 10, diam. 9.5 Mm."

Remarks. The description was based on a single specimen from the Paetel collection, which can be concluded from the sentence "das abgebildete Exemplar" [the figured specimen]. The present specimen corresponds perfectly with the original figure and the measurements given by Kobelt in Küster \& Kobelt (1888). It is the holotype.

The name is considered to be a junior synonym of Pascahinnites coruscans coruscans (Hinds, 1845) (Dijkstra \& Kilburn, 2001; Paulay, 2003), placed in the family Pectinidae. The species occurs in tidal to sublittoral habitats throughout the Indo-Pacific.

\section{Pecten (Chlamys) tamsi Bavay, 1906} (Figure 4e)

Bavay, 1906: 243-245, pl. 7, fig. 1

Type locality. "Puerto-Cabello Venezuelae" (Puerto Cabello, Venezuela).

Type material. Holotype ZMB Moll. 55.793 ("Porto Cab./Tams", typical green label of the Dunker collection; "Pecten (Chlamys) tamsi *Bavay/Puerto Cabello Venezuela/Musée de l'université Berlin", typical printed label of Bavay; a pair of articulated valves: $\mathrm{H}=28 \mathrm{~mm}, \mathrm{~L}=27 \mathrm{~mm}$ ). Inside the left valve an original label is glued with Bavay's handwriting in ink "P. tamsi sp. nov. Puerto Cabello".

Cited measurements by Bavay (1906: 243): "alt.: $28 \mathrm{~mm}$; long.: $26 \mathrm{~mm}$; crass. $10 \mathrm{~mm}$."

Remarks. The description is based on a single specimen from the ZMB collection, hence the holotype. The name is a junior synonym of Lindapecten exasperatus (G. B. Sowerby II, 1842) in the family Pectinidae, according to Dijkstra (1994) and Petuch (1995). Another junior synonym is Pecten (Aequipecten) acanthodes Dall, 1925. The species lives in the littoral and sublittoral throughout the Caribbean Sea (tropical western Atlantic).

\section{Pecten (Janira) turtoni E. A. Smith, 1890} (Figure 4f)

\section{E. A. Smith, 1890: 306-307, pl. 22, figs 10, 10a}

Type locality. Southeastern Atlantic, Saint Helena.

Type material. Eight potential syntypes ZMB Moll. 44.537 ("Pecten turtoni/E. Sm./St. Helena/Turton S. G./44537”; 3 right valves, 5 left valves from different individuals; obtained from Turton).

Three syntypes BMNH 1889.10.1.2424-6, matching valves. The largest specimen is figured by Smith (1890: pl. 22, figs 10, 10a).
Possible syntypes (4 valves) are also preserved in MNHN (not registered).

Cited measurements by E. A. Smith (1890: 306): "Longit. et latit. 32-34 millim."

Remarks. The present shells are not marked or catalogued as type material. Because they have been obtained from the author of the species description, we assume that they are part of the type series. The taxonomic position of the present species is Euvola turtoni (Smith, 1890), placed in the family Pectinidae. Raines \& Poppe (2006) treated this taxon as a junior synonym of Euvola ziczac (Gmelin, 1791), but personal observations of the senior author confirm that both taxa are valid species. The present species is only recorded from Saint Helena.

\section{Pecten (Dentipecten) vellicatus Hutton, 1873 (Figure 4i)}

Hutton, 1873: 82

Type locality. Not specified (= New Zealand, Recent).

Type material. Three syntypes ZMB Moll. 23.829 ("convexus Q.G./ Pecten roseopunctatus Rv/vellicatus Hutt./Neuseeland/Hutton/23829”, typical ZMB label in the handwriting of von Martens, catalogued as types of $P$. vellicatus Hutton; pair of valves and two single right valves; a) $\mathrm{H}=28.7 \mathrm{~mm} \mathrm{~L}=27.9 \mathrm{~mm}$, b) $\mathrm{H}=35.4 \mathrm{~mm} \mathrm{~L}=37.5 \mathrm{~mm}$, c) $\mathrm{H}=44.2 \mathrm{~mm} \mathrm{~L}=48.0 \mathrm{~mm}$ ).

According to Marshall (1996: 46), type material in New Zealand is lost.

Cited measurements by Hutton (1873: 82): "Height, 1.6 (inch); breadth, 1.6 (inch)."

Remarks. This name is a junior synonym of Mesopeplum convexum (Quoy \& Gaimard, 1835), placed in the family Pectinidae. The species lives sublittorally and bathyally off New Zealand.

\section{Pecten vesiculosus Dunker, 1877}

(Figure 4h)

Dunker, 1877: 72

Dunker, 1882: 241, pl. 11, fig. 1

Küster \& Kobelt, 1888: 138-139, pl. 38, fig. 4

Hayami, I., 1984: 105-109, pl. 3, fig. 5, pl. 4, figs 1-3, pl. 5, figs $1-$

3 , pl. 6 , figs $1-6$, pl. 7 , figs $1-10$, pl. 10 , figs 1,2 , pl. 11 , figs 1 ,

2 , pl. 12 , fig. 12 , pl. 13 , figs 1,2

Type locality. "maris Japonici” (Sea of Japan).

Type material. Lectotype, present designation, ZMB Moll. 114.473 ("P. vesiculosus Dkr", "Japan", in the handwriting of Dunker; pair of articulated valves: $\mathrm{H}=22.0 \mathrm{~mm}, \mathrm{~L}=22.0 \mathrm{~mm}$ ).

Potential paralectotype ZMB Moll 114.610 (label lettered on both sides in the handwriting of Dunker; side A: "Pect. tissoti Loven 1858 p. 91"; side B: “vesiculosus Dkr./T 11. f. 1", "Japan"; pair of disarticulated valves)

Cited measurements by Dunker (1877: 72): “Alt. spec. maximi 27 mill."

Remarks. Dunker (1877) provided measurements for a single shell, which is not interpreted as designation of a holotype. The text of the description is silent in regard to the number of specimens on which it is based. 
Following recommendation 73F (Avoidance of assumption of holotype) of the ICZN (1999), the specimen ZMB 114.473 is not considered as the holotype. It matches the measurements provided in the description and is designated as the lectotype. A second specimen, ZMB 114.610, most likely is a further type. However, because the original label of Dunker gives two different species names, the type status is considered not definite.

The current taxonomic position of the present pectinid species is Cryptopecten vesiculosus (Dunker, 1877). It lives sublittoral and bathyal in the Sea of Japan southwards to the South China Sea.

\section{Acknowledgements}

The senior author wishes to express his gratitude to the late $\mathrm{Dr}$. Rudolf Kilias, who assisted him during his visit in May 1989 with valuable information concerning the pectinoid type material. Many thanks are expressed to the late Dr. Nibaldo Bahamonde, Dr. Oscar Gálvez Herrera and Dr. Sergio Letelier of the Museo Nacional de Historia Natural at Santiago de Chili for providing information on Philippi's type material. Thanks are also due to Drs Alan Beu, Rüdiger Bieler and Paula Mikkelsen for their constructive comments on the manuscript.

\section{References}

Barnard, K. H. 1963. Deep-sea Mollusca from the region south of Madagascar. - South Africa Division of Sea Fisheries Investigational Report No. 44: 1-19.

Bavay, A. 1906. Sur quelques espèces ou variétés nouvelles du genre Pecten. - Journal de Conchyliologie 53: 243-247.

Bavay, A. 1909. Pecten multisquamatus Dunker et Pecten radiatus Hutton. - Bulletin du Muséum National d'Histoire Naturelle 40: $277-280$.

Beu, A. G. 1995. Pliocene limestones and their scallops. Lithostratigraphy, pectinid biostratigraphy and paleogeography of eastern North Island Late Neogene limestone. - Institute of Geological \& Nuclear Sciences Monograph 10: 1-243.

Boreham, A. U. E. 1959. Biological type specimens in the New Zealand Geological Survey. 1. Recent Mollusca. New Zealand Geological Survey Paleontological Bulletin 30: 1-87.

Dijkstra, H. H. 1994. De Pectinidae en Propeamussiidae van de A.B.C.-eilanden. In Coomans-Eustatia, M., Moolenbeek, R., Los, W. \& Prins, P. (eds). De Horen en zijn echo. Stichting Libri Antilliani, Bloemendaal and Zoölogisch Museum Amsterdam, Amsterdam: pp. 44-52. [In Dutch]

Dijkstra, H. H. 1998a. Pectinoidea (Mollusca: Bivalvia: Pectinidae: Propeamussiidae) from Hansa Bay, Papua New Guinea. - Molluscan Research 19: 11-52.

Dijkstra, H. H. 1998b. Notes on taxonomy and nomenclature of Pectinoidea (Mollusca: Bivalvia: Propeamussiidae, Pectinidae) 3. Nomina nova. - Basteria 62: 245-261.

Dijkstra, H. H. \& Goud, J. 2002. Pectinoidea (Bivalvia, Propeamussiidae \& Pectinidae) collected during the Dutch CANCAP and MAURITANIA expeditions in the south-eastern region of the North Atlantic Ocean. - Basteria 66: 31-82.

Dijkstra, H. H. \& Kilburn, R. N. 2001. The family Pectinidae in South Africa and Mozambique (Mollusca: Bivalvia: Pectinoidea). African Invertebrates 42: 263-321.

Dijkstra, H. H. \& Marshall, B. A. 1997. Pectinoidea (Mollusca: Bivalvia: Propeamussiidae: Pectinidae) of Lord Howe Island, Norfolk
Island and the Kermadec Islands. - Molluscan Research 18: $73-$ 114.

Dunker, W. 1853. Index Molluscorum, in itinere ad guineam inferiorem collegit Georgius Tams Med. Dr. Accedunt novarum specierum diagnoses, cirripedia nonnulla et $\mathrm{x}$. tabulae iconum. Theodori Fischer, Casselis Cattorum: [vi] + pp. 74

Dunker, W. 1864. Fünf neue Mollusken. - Malakozoologische Blätter 11: $99-102$.

Dunker, W. 1858-1870. Novitates Conchologicae. Mollusca Marina Theodor Fischer, Cassel: pp. 144.

Dunker, W. 1877. Mollusca nonnulla nova maris Japonici. - Malakozoologische Blätter 24: 67-75.

Dunker, W. 1882. Index molluscorum maris Japonici concriptus et tabulis iconum XVI illustratus. Theodori Fischer, Cassellis Cattorum: vii + pp. 301 .

Egorova, E. N. 1985. Bivalve molluscs in Antarctica. - Conchiglia 16: $18-23$.

Fernández Milera, J., Bidart, L., Feijoó, M. d. 1. A. \& Correoso, A 2002. Contribución de Gundlach a la malacofauna de Cuba. In Dathe, W. \& González López, R. M. (eds). Johann Christoph Gundlach (1810-1896): Un naturalista en Cuba/Naturforscher auf Kuba. Basilisken-Presse, Marburg an der Lahn: pp. 171180.

Fleming, C. A. 1976. Pecten (Chlamys) suteri Hertlein, 1933, a neglected nom. nov. for Pecten radiatus Hutton (preoccupied). Bulletin of the Conchology Section of the Auckland Museum (New Series), No. 1: 28.

Grau, G. 1959. Pectinidae of the eastern Pacific. Allan Hancock Pacific Expeditions, volume 23. University of Southern California Press, Los Angeles: viii + pp. 308.

Hain, S. 1990. Die beschalten benthischen Mollusken (Gastropoda und Bivalvia) des Weddellmeeres, Antarktis/The benthic seashells (Gastropoda and Bivalvia) of the Weddell Sea, Antarctic. - Berichte zur Polarforschung/Reports on Polar Research 70: 1-180.

Hayami, I. 1984. Natural history and evolution of Cryptopecten (a Cenozoic-Recent pectinid genus). - The University Museum, The University of Tokyo, Bulletin No. 24: i-ix, 1-149.

Hertlein, L. G. 1933. Three preoccupied names in the Pectinidae. The Nautilus 47: 62-64.

Hertlein, L. G. 1935. The Templeton Crocker Expedition of the California Academy of Sciences, 1932, No. 25. The Recent Pectinidae. - Proceedings of the California Academy of (Natural) Sciences (4) 21: 301-326.

Hertlein, L. G. 1936. The dates of publication of "C. H. Küster and W. Kobelt's Monograph of Spondylus und Pecten" in Volume 7, part 2, of the 'Systematisches Conchylien-Cabinet.' - Annals and Magazine of Natural History (10) 17: 158-160.

Hutton, F. W. 1873. Catalogue of the marine Mollusca of New Zealand, with diagnoses of the species. Didsbury, Government Printer, Wellington: pp. 116

ICZN (International Commission on Zoological Nomenclature) 1999. International code of zoological nomenclature. The International Trust for Zoological Nomenclature, c/o The Natural History $\mathrm{Mu}-$ seum, London: xxix + pp. 306

Jones, K. H. \& Preston, H. B. 1904. List of Mollusca collected during the expedition of H.M.S. "Waterwitch" in the China Seas, 19001903, with descriptions of new species. - Proceedings of the Malacological Society of London 6: 138-151.

Jonkers, H. A. 2003. Late Cenozoic-Recent Pectinidae (Mollusca: Bivalvia) of the Southern Ocean and neighbouring regions. Monographs of Marine Mollusca No. 5. Backhuys Publishers, Leiden: viii + pp. 125.

Küster, C. H. \& Kobelt, W. 1885-1888. Die Gattungen Spondylus und Pecten. In Küster, C. H. \& Kobelt, W. (eds). Systematisches Conchylien-Cabinet von Martini und Chemnitz 7 (2). Raspe, Nürnberg: pp. 1-296. [For publication dates, see Hertlein (1936), and Rehder (1952)] 
Marshall, B. A. 1996. Molluscan name-bearing types in the Museum of New Zealand Te Papa Tongarewa. Tuhinga. - Records of the Museum of New Zealand Te Papa Tongarewa 9: 1-85.

Martens, E. von 1881a. Conchologische Mitteilungen als Fortsetzung der Novitates Conchologicae I, Parts 5-6. Theodor Fischer Kassel: pp. 73-101; II, Parts 1-2: pp. 103-128.

Martens, E. von 1881b. Mehrere von Sr. Maj. Schiff Gazelle von der Magalhaenstrasse, der Ostküste Patagoniens un der KerguelenInsel mitgebrachte Meeres-Conchylien. - Sitzungs-Berichte der Gesellschaft Naturforschender Freunde zu Berlin 1881: 75-80.

Paulay, G. 2003. Marine Bivalvia (Mollusca) of Guam. - Micronesica 35-36: 218-243.

Petuch, E. J. 1995. Molluscan discoveries from the tropical western Atlantic region. - Conchiglia (The Shell) 27 (275): 36-41.

Philippi, R. A. 1845. Diagnosen einiger neuen Conchylien. - Archiv für Naturgeschichte 11: 50-71.

Philippi, R. A. 1851. Centuria quinta Testaceorum novorum. - Zeitschrift für Malakozoologie 8 (6): 29-96, 123-126.

Powell, A. W. B. 1960. Antarctic and subantarctic Mollusca. Records of the Auckland Institute and Museum 5 (3): 117-193.

Powell, A. W. B. 1979. New Zealand Mollusca. Marine, land and freshwater shells. Collins, Auckland: xiv + pp. 500 .

Raines, B. K. \& Poppe, G. T. 2006. A conchological iconography. The family Pectinidae. ConchBooks, Hackenheim: pp. 402.

Ramsden, C. T. 1915. Juan Gundlach. - Entomological News and Proceedings of the Entomological Section of the Academy of Natural Sciences of Philadelphia 26: 241-260.

Reeve, L. A. 1852-1853. Monograph of the genus Pecten. In Conchologica Iconica: or, Illustrations of the Shells of Molluscous Animals, vol. 8. Lovell Reeve, London: [unnumbered pages], 35 pls [pls $1-12+$ text (1852), pls 13-35 + text + index (1853)].

Rehder, H. A. 1952. The publication dates of Kobelt's "Illustriertes Conchylienbuch". - The Nautilus 66: 59-60.

Roth, B. 1975. Description of a new species of pectinid bivalve from the Juan Fernandez Islands, Chile. - Journal of the Malacological Society of Australia 3: 81-87.

Smith, E. A. 1885. Report on the Lamellibranchiata collected by H.M.S. "Challenger" during the years 1873-1876. Report on the Scientific Results of the Voyage of H.M.S. "Challenger" During the Years 1873-1876, Zoology 13 (35): 1-341.
Smith, E. A. 1890. Report on the marine molluscan fauna of the island of St. Helena. - Proceedings of the Zoological Society of London 18: 247-317.

Smith, E. A. 1906. Natural history notes from R.I.M.S. "Investigator". Series III, No. 10. On Mollusca from the Bay of Bengal and the Arabian Sea. - The Annals and Magazine of Natural History (7) 18: $157-175,245-264$.

Sowerby G. B. II 1842. Monograph of the genus Pecten. Thesaurus Conchyliorum, or monographs of genera of shells. Vol. 1: Sowerby, London: pp. 45-78, 81-82.

Stempell, W. 1899. Die Muscheln der Sammlung Plate. Fauna Chilensis, volume 2. - Zoologische Jahrbücher, Suppl. 5: 217-250.

Suter, H. 1909. Descriptions of new species and subspecies of New Zealand Mollusca, with notes on a few species. - Proceedings of the Malacological Society of London 8: 253-265.

Suter, H. 1913. Manual of the New Zealand Mollusca. With an atlas of quarto plates (1915). Government Printer, Wellington: pp. 1120.

Thiele, J. 1912. Die antarktischen Schnecken und Muscheln. Deutsche Südpolar-Expedition 1901-1903, (2) 13, Zoologie, 5: $183-285$.

Thiele, J. \& Jaeckel, S. 1931. Muscheln der Deutschen TiefseeExpedition. Wissenschaftliche Ergebnisse der Deutschen TiefseeExpedition auf dem Dampfer "Valdivia" 1898-1899, 21 (1): 159-268.

Wagner, H. P. 1989. The genus Cryptopecten Dall, Bartsch \& Rehder, 1938, in the Indo-Pacific (Mollusca; Bivalvia; Pectinidae). - Basteria 53: 53-62.

Waller, T. R. 1972. The Pectinidae (Mollusca, Bivalvia) of Eniwetok Atoll, Marshall Islands. - The Veliger 14: 221-264.

Waller, T. R. 1993. The evolution of "Chlamys" (Mollusca: Bivalvia: Pectinidae) in the tropical western Atlantic and eastern Pacific. American Malacological Bulletin 10: 195-249.

Waloszek, D. 1984. Variabilität, Taxonomie und Verbreitung von Chlamys patagonica (King \& Broderip, 1832) und Anmerkungen zu weiteren Chlamys-Arten von der Südspitze Süd-Amerikas (Mollusca, Bivalvia, Pectinidae). - Verhandlungen des Naturwissenschaftlichen Vereins in Hamburg (NF) 27: 207-276.

Wang, Z. 2002. Fauna Sinica, Invertebrata, vol. 31, Mollusca, Bivalvia, Pteriina. Science Press, Beijing: $\mathrm{x}+$ pp. 374. [In Chinese]. 